\title{
Phenethyl Isothiocyanate Induces Apoptotic Cell Death Through the Mitochondria-dependent Pathway in Gefitinib- resistant NCI-H460 Human Lung Cancer Cells In Vitro
}

\author{
TE-CHUN HSIA ${ }^{1,2}$, YI-PING HUANG ${ }^{3}$, YI-WEN JIANG ${ }^{4}$, HSIN-YU CHEN ${ }^{4}$, \\ ZHENG-YU CHENG ${ }^{5}$, YUNG-TING HSIAO ${ }^{5}$, CHENG-YEN CHEN ${ }^{5}$, SHU-FEN PENG $^{6}$, \\ FU-SHIN CHUEH ${ }^{7}, \mathrm{YU}_{-\mathrm{CHENG}} \mathrm{CHOU}^{8,9^{*}}$ and JING-GUNG $\mathrm{CHUNG}^{5,10^{*}}$ \\ ${ }^{I}$ Department of Respiratory Therapy, China Medical University, Taichung, Taiwan, R.O.C.; \\ ${ }^{2}$ Department of Internal Medicine, China Medical University Hospital, Taichung, Taiwan, R.O.C.; \\ ${ }^{3}$ Department of Physiology, College of Medicine, China Medical University, Taichung, Taiwan, R.O.C.; \\ ${ }^{4}$ Department of Chinese Pharmaceutical Sciences and Chinese Medicine \\ Resources, China Medical University, Taichung, Taiwan, R.O.C.; \\ ${ }^{5}$ Department of Biological Science and Technology, China Medical University, Taichung, Taiwan, R.O.C.; \\ ${ }^{6}$ Department of Medical Research, China Medical University Hospital, \\ China Medical University, Taichung, Taiwan, R.O.C.; \\ ${ }^{7}$ Department of Health and Nutrition Biotechnology, Asia University, Taichung, Taiwan, R.O.C.; \\ ${ }^{8}$ Division of Neurosurgical Oncology, Neurological Institute, Taichung \\ Veterans General Hospital, Taichung, Taiwan, R.O.C.; \\ ${ }^{9}$ Department of Neurological Surgery, Tri-Service General Hospital, \\ National Defense Medical Center, Taipei, Taiwan, R.O.C.; \\ ${ }^{10}$ Department of Biotechnology, Asia University, Taichung, Taiwan, R.O.C.
}

\begin{abstract}
Background/Aim: Some lung cancer patients treated with gefitinib develop resistance to this drug resulting in unsatisfactory treatment outcomes. Phenethyl isothiocyanate (PEITC), present in our common cruciferous vegetables, exhibits anticancer activities in many human cancer cell lines. Currently, there is no available information on the possible modification of gefitinib resistance of lung cancer in vitro by PEITC. Thus, the effects of PEITC on gefitinib resistant lung cancer NCI-H460 cells were investigated in vitro. Materials and Methods: The total cell viability, apoptotic cell death, production of reactive oxygen species (ROS) and $\mathrm{Ca}^{2+}$, levels
\end{abstract}

*These Authors contributed equally to this study.

Correspondence to: Prof. Jing-Gung Chung, Department of Biological Science and Technology, China Medical University, No 91, Hsueh-Shih Road, Taichung, Taiwan, ROC. Tel: +886 422053366, ext. 8000, Fax: +886 422053764, e-mail: jgchung@mail.cmu.edu.tw; Yu-Cheng Chou, Division of Neurosurgical Oncology, Neurological Institute, Taichung Veterans General Hospital, Taichung, Taiwan, ROC. Tel: +886 423592525, Fax: +886 423592705, e-mail: chouycns@yahoo.com.tw

Key Words: Phenethyl isothiocyanate, gefitinib, apoptosis, NCIH460 human lung cancer cells. of mitochondria membrane potential $\left(\Delta \Psi_{m}\right)$ and caspase-3, -8 and -9 activities were measured by flow cytometry assay. PEITC induced chromatin condensation was examined by DAPI staining. Results: PEITC-induced cell morphological changes, decreased total viable cell number and induced apoptotic cell death in NCI-H460 and NCI-H460/G cells. PEITC decreased ROS production in NCI-H460 cells, but increased production in NCI-H460/G cells. PEITC increased $\mathrm{Ca}^{2+}$ production, decreased the levels of $\Delta \Psi_{m}$ and increased caspase-3, -8 and 9 activities in both NCI-H460 and NCI-H460/G cells. Western blotting was used to examine the effect of apoptotic cell death associated protein expression in NCI-H460 NCI-H460/G cells after exposure to PEITC. Results showed that PEITC increased expression of cleaved caspase-3, PARP, GADD153, Endo G and pro-apoptotic protein Bax in NCI-H460/G cells. Conclusion: Based on these results, we suggest that PEITC induces apoptotic cell death via the caspase- and mitochondriadependent pathway in NCI-H460/G cells.

Lung cancer is the leading cause of cancer-associated death in the human population worldwide (1). About $80-85 \%$ of lung cancers are non-small cell lung cancers (NSCLC) (2, 3). Worldwide, an estimated 1,098,700 men and 491,200 women died from lung cancer in 2012, corresponding to 
$24 \%$ and $14 \%$ of all cancer deaths in males and females, respectively (4). In Taiwan, lung cancer is currently the first most common cancer, regardless of gender, and about 39.9 individuals per 100,000 die annually from lung cancer (5) (report from the Ministry of Health and Welfare, Taiwan, R.O.C. in 2016). The primary treatments for lung cancer include surgery, radiotherapy and chemotherapy (5). In recent years, treatment, detection of lung cancer and the 5 -year survival rate have improved, but the development of drug resistance remains a serious clinical problem. Gefitinib (IRESSA ${ }^{\circledR}$, AstraZeneca) (inhibitor of the epidermal growth factor receptor) (6), has been used for NSCLC patients with EGFR mutations (7) but some patients develop resistance (8). Thus, many studies have focused on finding new compounds from natural products for lung cancer patients.

Phenethyl isothiocyanate (PEITC), a member of isothiocyanates (ITCs), induce cancer cell apoptosis in many human cancer cell lines $(9,10)$ including non-small cell lung cancer cells (11). PEITC inhibited metastasis of highly metastatic lung cancer L9981 cells by inducing apoptosis and cell cycle arrest, via targeting the MAPK/AP-1 pathway (11) and inducing disassembly of actin stress fibers and degradation of tubulin which contribute to the induction of cell death (12). The anti-proliferative effects of PEITC result from the upregulation of death receptor 4 (DR4) and DR5 of the tumor necrotic factor-related apoptosis-inducing ligand (TRAIL)-mediated apoptotic pathway in human HeLa cancer cells (13). PEITC inhibited the growth of human glioma LN229 cells by inducing oxidative stress (14). PEITC induced apoptosis in human prostate cancer LNCaP cells potentially by reactivating Ras-association domain family 1 isoform A (RASSF1A) via epigenetic mechanisms (15). Recently, we found that PEITC inhibited murine melanoma $\mathrm{B} 16 \mathrm{~F} 10$ cell migration and invasion in vitro (16).

Numerous studies have shown that PEITC induces apoptotic cell death in many human cancer cell lines; however, there is no report on NCI-H460 gefitinib-resistant cells in vitro. Therefore, we aimed to study the effects of PEITC on NCI-H460 gefitinib-resistant human lung cancer cells. Results showed that PEITC decreased the total viable cell number via the induction of apoptotic cell death through mitochondria and the production of reactive oxygen species.

\section{Materials and Methods}

Chemicals and reagents. Phenethyl isothiocyanate (PEITC), propidium iodide (PI), Tris- $\mathrm{HCl}$, trypsin, trypan blue and dimethyl sulfoxide (DMSO, as a carrier solvent) were obtained from Sigma Chemical Co. (St. Louis, Missouri, USA). PEITC was dissolved in DMSO as a stock for further experiments. Cell culture medium (RPMI-1640), fetal bovine serum and penicillin-streptomycin were purchased from Invitrogen (Carlsbad, California, USA).

Cell culture. The NCI-H460 human lung cancer cell line was obtained from the Food Industry Research and Development
Institute (Hsinchu, Taiwan) and cultured in RPMI-1640 medium supplemented with $10 \%$ fetal bovine serum (FBS), $0.1 \mathrm{mg} / \mathrm{ml}$ streptomycin, and 100 units $/ \mathrm{ml}$ penicillin at $37^{\circ} \mathrm{C}$ in an atmosphere of $5 \% \mathrm{CO}_{2}$ (17).

Establishment of gefitinib-resistant NCI-H460 human lung cancer cells. Gefitinib-resistant NCI-H460 cells were generated with the exposure of increasing concentrations of gefitinib. Firstly, NCI-H460 cells were cultured in RPMI-1640 medium containing gefitinib at the concentration of $1 / 2$ of the $50 \%$ growth inhibition $\left(\mathrm{IC}_{50}\right)$. Secondly, cells were sub-cultured in RPMI-1640 medium with $25 \%$ increased concentrations of gefitinib every 2 weeks. After treatment, the resultant cells that grew exponentially in high concentration of gefitinib were recognized to be the gefitinib-resistant human lung cancer cell line (NCI-H460/G) as described previously (17). The fold resistance was calculated using the following equation:

Fold Resistance $=\mathrm{IC}_{50}$ of Resistant Cell Line $/ \mathrm{IC}_{50}$ of Parental Cell Line $(18,19)$.

Cell morphological changes and viability assay. NCI-H460 cells $\left(1 \times 10^{5}\right.$ cells/well $)$ were treated with gefitinib $(40 \mu \mathrm{M})$ or PEITC $(0,10,25,50$ and $100 \mu \mathrm{M})$. NCI-H460/G cells $\left(1 \times 10^{5}\right.$ cells/well $)$ were treated with PEITC $(0,7,10,13$ and $16 \mu \mathrm{M})$ for $48 \mathrm{~h}$. After incubation, cells were examined and photographed under contrastphase microscopy. Cells were harvested and stained with PI $(5 \mu \mathrm{g} / \mathrm{ml})$ for cell viability by flow cytometry (Becton-Dickinson, San Jose, California, USA) as described previously (20).

Apoptotic cell death assay. NCI-H460 or NCI-H460/G cells $\left(1 \times 10^{5}\right.$ cells/well) were incubated with or without $40 \mu \mathrm{M}$ of gefitinib for $48 \mathrm{~h}$ or with PEITC ( $25 \mu \mathrm{M}$ or $10 \mu \mathrm{M}$, respectively) for $6,12,24$ and $48 \mathrm{~h}$. Cells were harvested and stained with Annexin V/PI double staining for total apoptotic cell death analysis by flow cytometry as described previously (20).

DAPI assay. NCI-H460 or NCI-H460/G cells $\left(1 \times 10^{5}\right.$ cells/well $)$ were incubated with or without $40 \mu \mathrm{M}$ of gefitinib for $48 \mathrm{~h}$ or with PEITC ( $25 \mu \mathrm{M}$ or $10 \mu \mathrm{M}$, respectively) for $6,12,24$ and $48 \mathrm{~h}$. After incubation, cells were fixed in $3 \%$ paraformaldehyde in PBS at room temperature for $20 \mathrm{~min}$. After washed with PBS, cells were stained with DAPI solution $(2 \mu \mathrm{g} / \mathrm{ml})$ for examining DNA condensation and photographed using a fluorescence microscope as described previously (20).

Measurements of reactive oxygen species (ROS), intracellular $\mathrm{Ca}^{2+}$ and mitochondrial membrane potential $\left(\Delta \Psi_{m}\right)$. Flow cytometric assay was used for measuring the production of ROS and $\mathrm{Ca}^{2+}$ and levels of $\Delta \Psi_{m}$. NCI-H460 or NCI-H460/G cells $\left(1 \times 10^{5}\right.$ cells/well $)$ were treated with or without gefitinib $(40 \mu \mathrm{M})$ or PEITC $(25 \mu \mathrm{M}$ or $10 \mu \mathrm{M}$, respectively) for $6,12,24$ and $48 \mathrm{~h}$. After incubation, cells were harvested and re-suspended in $500 \mu \mathrm{l}$ of DCFH-DA $(10 \mu \mathrm{M})$, $500 \mu \mathrm{l}$ of Fluo-3/AM $(2.5 \mu \mathrm{g} / \mathrm{ml})$, and $500 \mu \mathrm{l}$ of $\mathrm{DiOC}_{6}(4 \mu \mathrm{mol} / \mathrm{l})$ for $30 \mathrm{~min}$ to measure the changes of $\operatorname{ROS}\left(\mathrm{H}_{2} \mathrm{O}_{2}\right)$, intracellular $\mathrm{Ca}^{2+}$ level, and $\Delta \Psi_{m}$ levels, respectively. All samples were analyzed by flow cytometry as described previously (20-22). All samples were analyzed in triplicate.

Measurements of caspase-3, -8 and -9 activities. NCI-H460 or NCI$\mathrm{H} 460 / \mathrm{G}$ cells $\left(1 \times 10^{5}\right.$ cells/well $)$ were incubated with gefitinib 
A

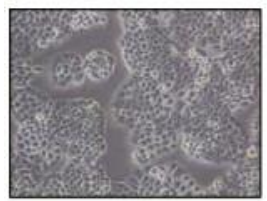

H460

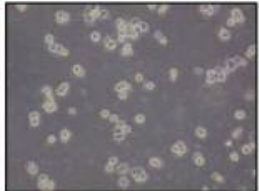

$25 \mu \mathrm{M}$
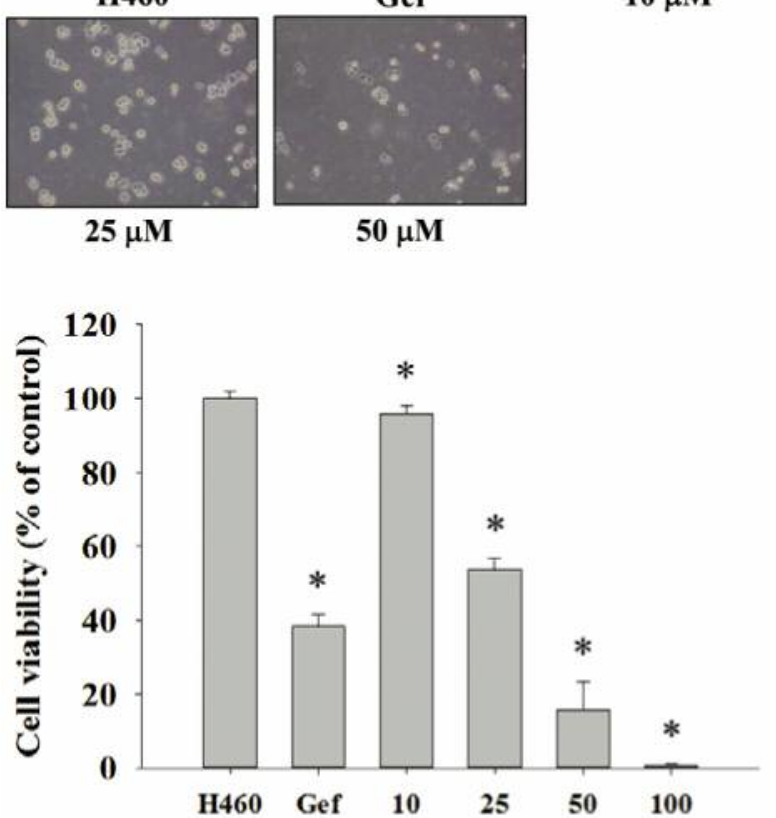

$\mathbf{5 0} \mu \mathbf{M}$
B

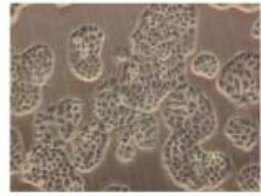

H460/G

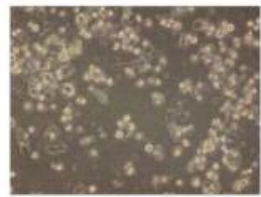

$13 \mu \mathrm{M}$

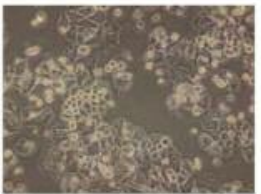

$7 \mu \mathrm{M}$

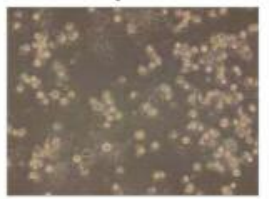

$16 \mu \mathrm{M}$

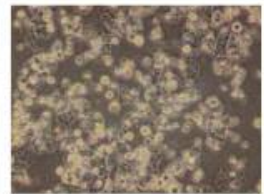

$10 \mu \mathrm{M}$

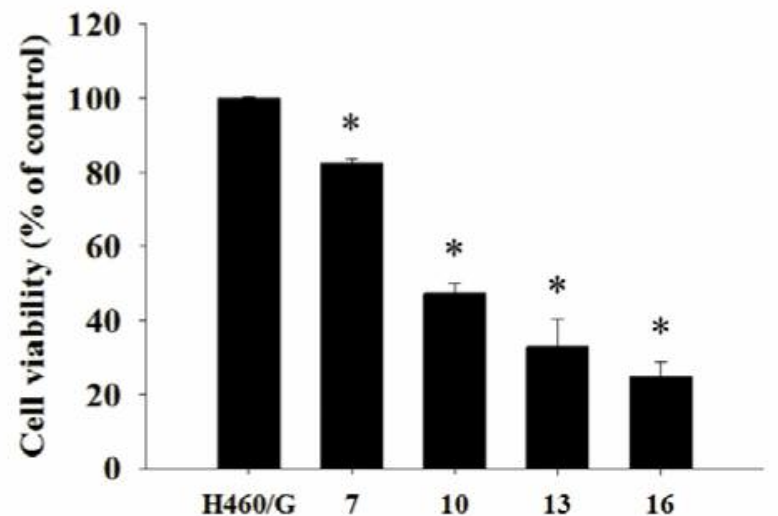

Figure 1. Gefitinib and PEITC induced cell morphological changes and decreased cell viability of NCI-H460 or NCI-H460/G cells. Cells (1 $\times 10^{5}$ cells/well) were treated with gefitinib and various concentrations of PEITC for $48 \mathrm{~h}$. Cells were examined and photographed for morphological changes and were harvested for total viable cell viability, as described in Materials and Methods. A: NCI-H460 cells. B: NCI-H460/G cells. *p<0.05, significant difference between of gefitinib or PEITC-treated group with control group as analyzed by Dunnett test.

(40 $\mu \mathrm{M})$ or PEITC $(25 \mu \mathrm{M}$ or $10 \mu \mathrm{M}$, respectively) for $6,12,24$ and $48 \mathrm{~h}$. Cells were collected and re-suspended in $25 \mu \mathrm{l}$ of $20 \mu \mathrm{M}$ substrate solutions (PhiPhiLux- $\mathrm{G}_{1} \mathrm{D}_{2}$, CaspaLux $8-\mathrm{L}_{1} \mathrm{D}_{2}$ and CaspaLux $9-M_{1} D_{2}$, respectively) of caspase-3, -8 and -9 for measuring the activity of the individual caspase using flow cytometry as previously described $(20,23)$.

Western blotting analysis. NCI-H460 or NCI-H460/G cells $\left(1 \times 10^{6}\right.$ cells/dish) were incubated with gefitinib $(40 \mu \mathrm{M})$ or PEITC $(25 \mu \mathrm{M}$ or $10 \mu \mathrm{M}$, respectively) for $6,12,24$ and $48 \mathrm{~h}$. Cells were collected and gently re-suspended in lysis buffer for sonication and centrifuged as described previously $(16,17)$ and supernatant was used for measuring total protein by the Bio-Rad protein assay kit (Bio-Rad, Hercules, CA, USA) with bovine serum albumin (BSA) as the standard $(17,20)$. Total cellular protein was electrophoresed on SDS polyacrylamide gels and then electrotransfered onto PVDF membrane (Millipore, Bedford, MA, USA), washed and incubated with primary antibodies (anti-AIF, -cleaved caspase-3, -caspase-9, -p65, -XIAP, -cytochrome c, -Bid, -Bax, -Endo G, -PARP, GADD153, -Calpain 1, -caspase-7, -GRP78, -IRE-1 $\alpha$, -ATF-6 $\alpha$, and $-\beta$-actin). After washed, the membranes were incubated with HRP conjugated anti-rabbit IgG. Immunoreactive proteins were visualized and detected by Immobilon ${ }^{\mathrm{TM}}$ Western Chemiluminescent HRP Substrate (Millipore, Billerica, MA, USA) $(17,20)$.

Statistical analysis. All data are expressed as the mean \pm standard deviation (SD) from at least 3 experiments. Differences between groups were analyzed by one-way analysis of variance and Dunnett test for multiple comparisons (SigmaPlot for Windows version 12.0; Systat Software, Inc., San Jose, CA, USA). Comparisons were made between groups of gefitinib or PEITC-treated group and control group. Differences with $p<0.05(*)$ were considered statistically significant.

\section{Results}

PEITC induced cell morphological changes and decreased cell viability in NCI-H460 and NCI-H460/G cells. NCIH460 or NCI-H460/G cells were treated with gefitinib or with various concentrations of PEITC for $48 \mathrm{~h}$, the cell morphological changes were photographed and total viability was measured and are presented in Figure 1A and $\mathrm{B}$, respectively. Results indicated that $40 \mu \mathrm{M}$ of gefitinib decreased over $50 \%$ of viable NCI-H460 cells (Figure 1A) 
A
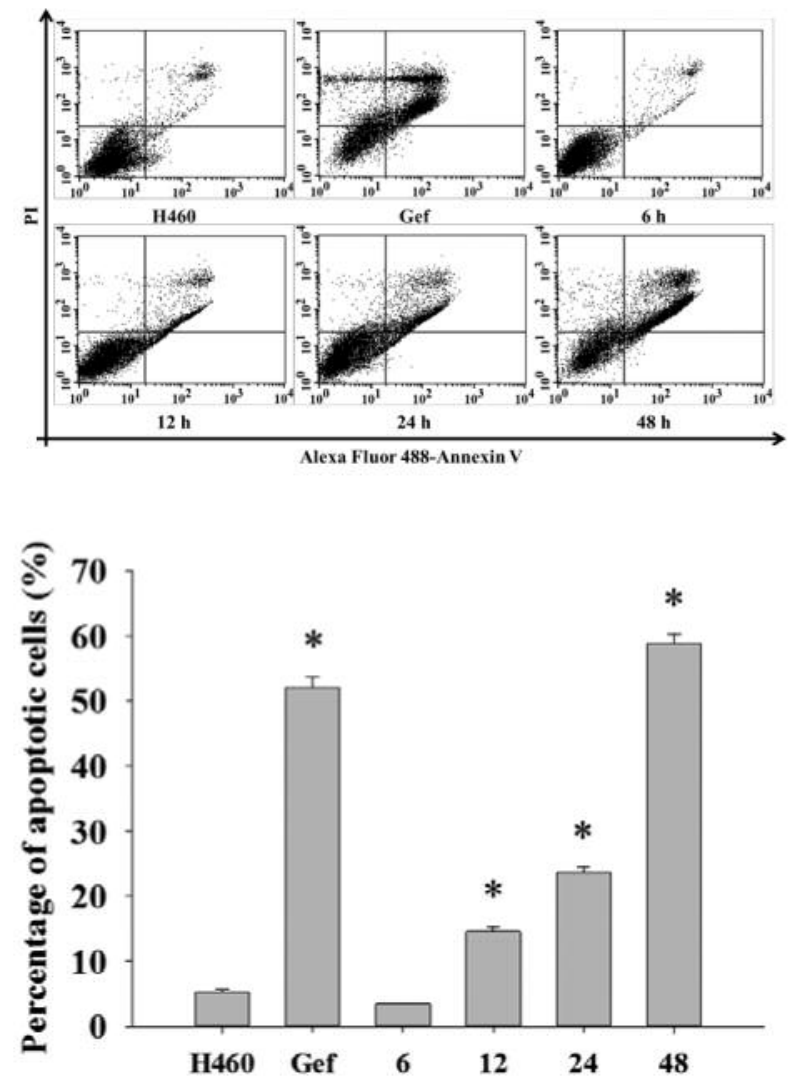

B
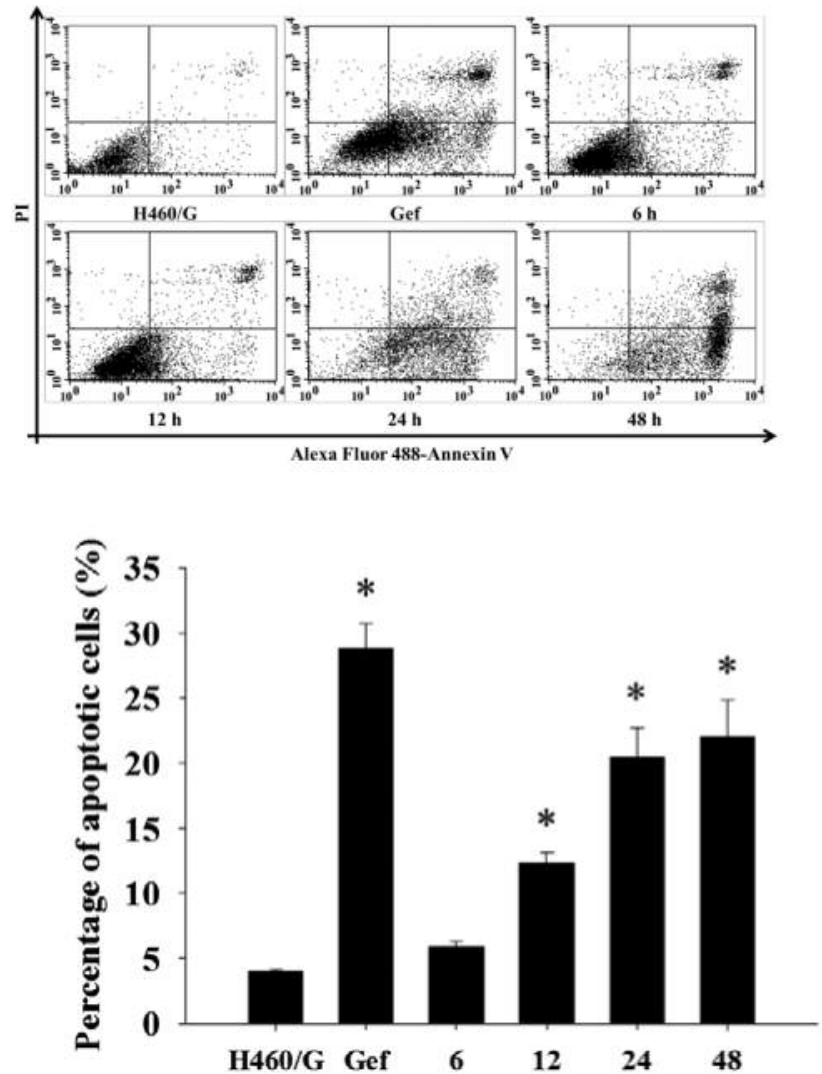

Figure 2. Gefitinib and PEITC induce apoptotic cell death in NCI-H460 and NCI-H460/G cells. Cells were treated with gefitinib (40 $\mu M)$ or PEITC $(25 \mu \mathrm{M}$ or $10 \mu \mathrm{M})$ for 6, 12, 24 and $48 \mathrm{~h}$ and measured for apoptotic cell death using Annexin-V/PI double staining as described in Materials and Methods. A: NCI-H460 cells. B: NCI-H460/G cells. ${ }^{*} p<0.05$, significant difference between of gefitinib or PEITC-treated group with control group as analyzed by Dunnett's test.

and PEITC induced cell morphological changes indicative of shrinkage and decreased viability of NCI-H460 (Figure 1A) or NCI-H460/G (Figure 1B) cells in a dose-dependent manner.

PEITC induced apoptotic cell death in NCI-H460 and NCI$H 460 / G$ cells. NCI-H460 or NCI-H460/G cells were treated with gefitinib $(40 \mu \mathrm{M})$ or PEITC $(25 \mu \mathrm{M}$ or $10 \mu \mathrm{M}$, respectively) for various time periods $(0,6,12,24$, and $48 \mathrm{~h}$ ) and apoptotic cell death was determined and presented in Figures $2 \mathrm{~A}$ and B. Results indicated that $40 \mu \mathrm{M}$ of gefitinib induced apoptotic cell death in NCI-H460 cells and PEITC induced apoptotic cell death in both NCI-H460 and NCI-H460/G cells in a time-dependent manner. However, there was more PEITC-induced apoptotic cell death in NCI$\mathrm{H} 460$ cells than in NCI-H460/G cells after $48 \mathrm{~h}$ treatment. PEITC induced chromatin condensation in NCI-H460 and NCI-H460/G cells. NCI-H460 or NCI-H460/G cells exposed to gefitinib $(40 \mu \mathrm{M})$ or PEITC $(25 \mu \mathrm{M}$ or $10 \mu \mathrm{M}$, respectively) for $6,12,24$ and $48 \mathrm{~h}$, cells were stained with DAPI, and visualized using fluorescence microscopy. Results are shown in Figures $3 \mathrm{~A}$ and B. A brighter fluorescence intensity was observed in NCI-H460 and NCI-H460/G cells after a $48 \mathrm{~h}$ treatment of PEITC $(25 \mu \mathrm{M}$ or $10 \mu \mathrm{M}$, respectively) (Figure $3 \mathrm{~A}$ and $\mathrm{B}$ ). The bright fluorescence is based on nicked DNA and chromatin condensation.

PEITC induced reactive oxygen species (ROS) and intracellular $\mathrm{Ca}^{2+}$ production and decreased the levels of mitochondrial membrane potential $\left(\Delta \Psi_{m}\right)$ in NCI-H460 and NCI-H460/G cells. NCI-H460 and NCI-H460/G cells exposed to gefitinib $(40 \mu \mathrm{M})$ or PEITC $(25 \mu \mathrm{M}$ and $10 \mu \mathrm{M}$, respectively) for $6,12,24$ and $48 \mathrm{~h}$ and cells were harvested in order to measure the production of ROS and $\mathrm{Ca}^{2+}$ and the levels of $\Delta \Psi_{m}$ using flow cytometric assay (Figures 4 ). As shown in Figure 4A, 6-48 h treatment led to decreased ROS 
A
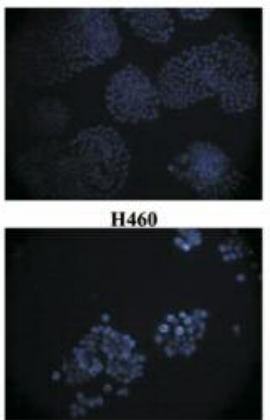

$12 \mathrm{~h}$
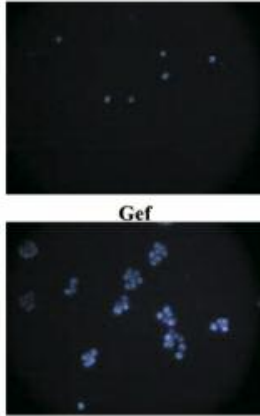

$24 \mathrm{~h}$
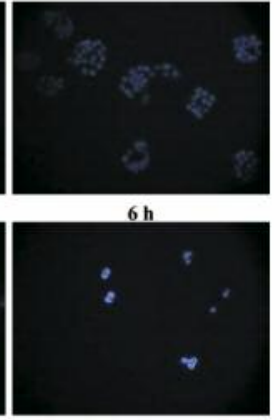

$48 \mathrm{~h}$
B

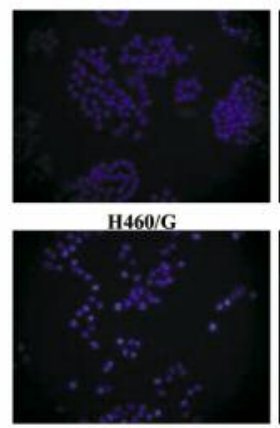

$12 \mathrm{~h}$
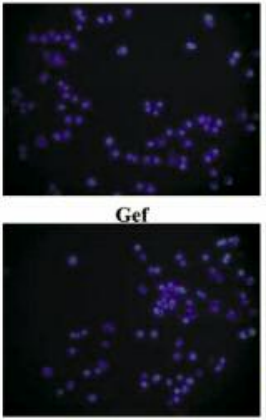

$24 \mathrm{~h}$
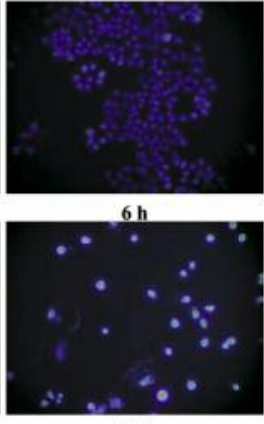

$48 \mathrm{~h}$
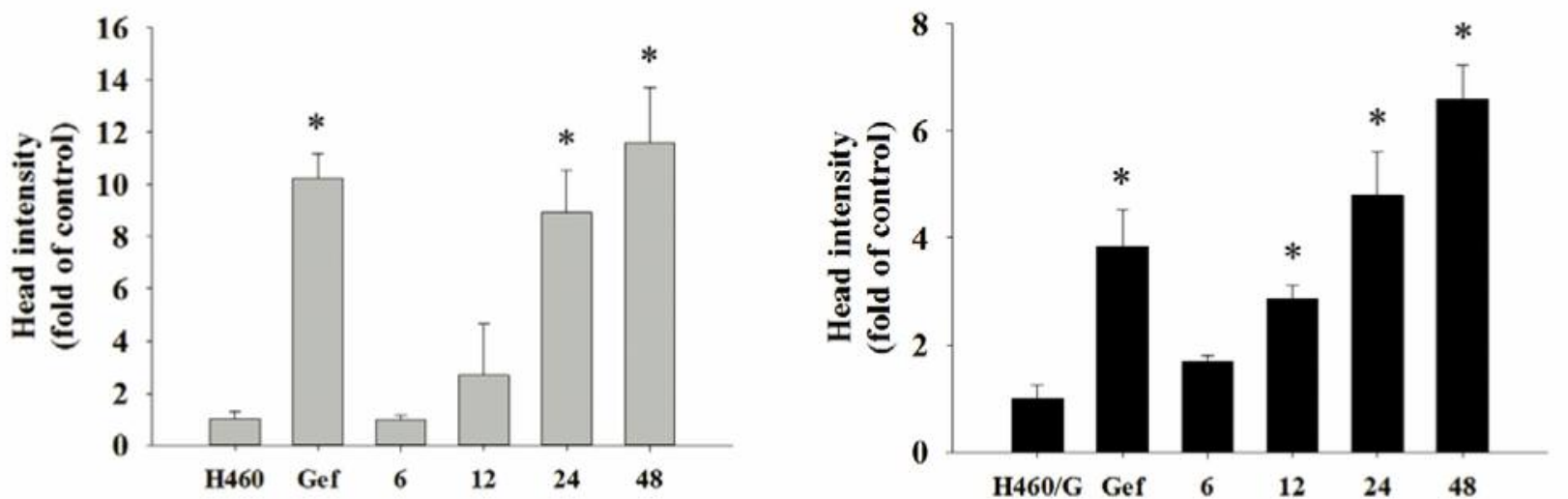

Figure 3. Gefitinib and PEITC induced chromatin condensation in NCI-H460 and NCI-H460/G cells. NCI-H460 and NCI-H460/G cells were treated with gefitinib $(40 \mu \mathrm{M})$ or PEITC (25 $\mathrm{M}$ or $10 \mu \mathrm{M})$ for $6,12,24$ and $48 \mathrm{~h}$ and were stained with DAPI, visualized using fluorescence microscopy and photographed as described in Materials and Methods. A: NCI-H460 cells. B: NCI-H460/G cells. *p<0.05, significant difference between of gefitinib or PEITC-treated group with control group as analyzed by Dunnett's test.

production in NCI-H460 cells. However, PEITC increased ROS production after 6-48 h treatment in NCI-H460/G cells (Figure 4B). PEITC increased $\mathrm{Ca}^{2+}$ release after $48 \mathrm{~h}$ treatment in NCI-H460 cells (Figure 4C) and also increased $\mathrm{Ca}^{2+}$ release after $24-48 \mathrm{~h}$ treatment in NCI-H460/G cells (Figure 4D). PEITC decreased the levels of $\Delta \Psi_{m}$ after 24$48 \mathrm{~h}$ treatment in NCI-H460 cells (Figure 4E) but only decreased the levels of $\Delta \Psi_{m}$ after $48 \mathrm{~h}$ treatment in NCI$\mathrm{H} 460 / \mathrm{G}$ cells (Figure 4F), however, gefitinib significantly decreased the level of $\Delta \Psi_{m}$ in NCI-H460 cells and increased the levels of $\Delta \Psi_{m}$ in NCI-H460/G cells.

PEITC induced caspase-3, -8 and -9 activities in NCI-H46O and NCI-H460/G cells. Cells were treated with gefitinib (40 $\mu \mathrm{M})$ or PEITC ( $25 \mu \mathrm{M}$ or $10 \mu \mathrm{M}$, respectively) for $6,12,24$ and $48 \mathrm{~h}$, harvested for measuring the activities of caspase-3, -8 and -9 . Results indicated that PEITC increased the activities of caspase-3 (Figure 5A and B) and caspase- 8
(Figure 5C and D) in NCI-H460 and NCI-H460/G cells. Furthermore, PEITC increased caspase-9 activity after 12-48 $\mathrm{h}$ treatment in NCI-H460 cells (Figure 5E); however, in NCI$\mathrm{H} 460 / \mathrm{G}$ cells, PEITC led to a decrease in caspase-9 activity after 6-24 h treatment and an increase after $48 \mathrm{~h}$ treatment (Figure 5F).

PEITC altered apoptosis-associated protein expression in $\mathrm{NCI}-\mathrm{H} 460$ and $\mathrm{NCI}-\mathrm{H} 460 / \mathrm{G}$ cells. In order to further analyze the molecular mechanisms of PEITC-induced apoptotic cell death in NCI-H460 and NCI-H460/G cells, apoptosis-associated protein expressions from PEITC treated cells were examined by western blotting as shown in Figure 6. Results indicated that PEITC increased expression of cleaved caspase-3, caspase-9, p65, XIAP, and cytochrome $c$, but decreased AIF in NCI-H460 cells (Figure 6A), however, PEITC only increased cleaved caspase-3, p65 and XIAP in NCI-H460/G cells (Figure 6B). Results in 
A

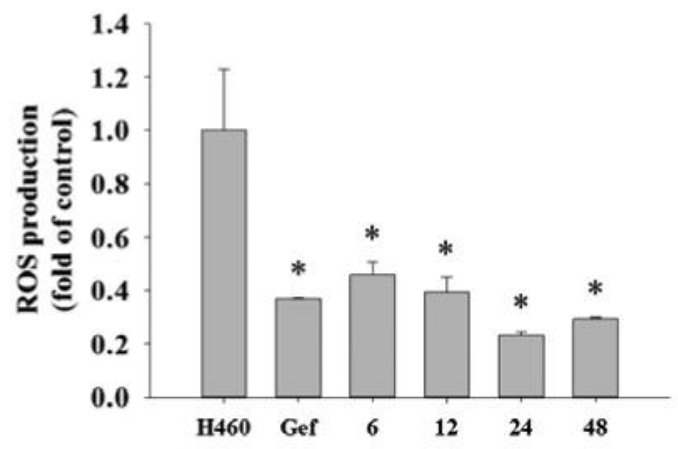

C

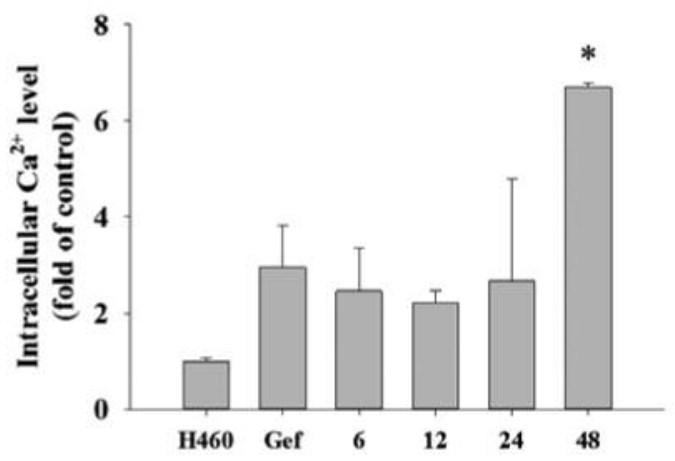

$\mathbf{E}$

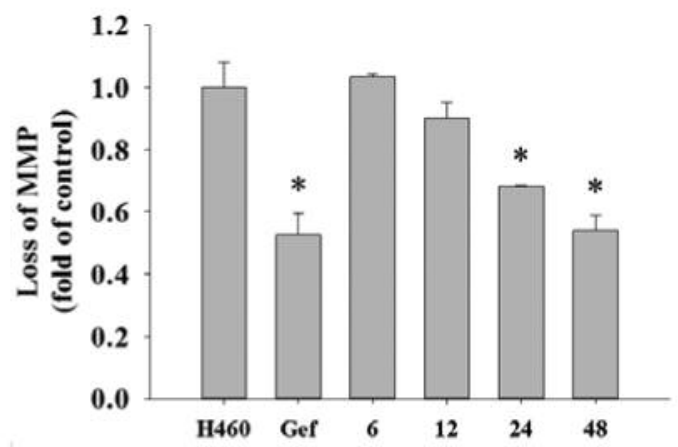

B

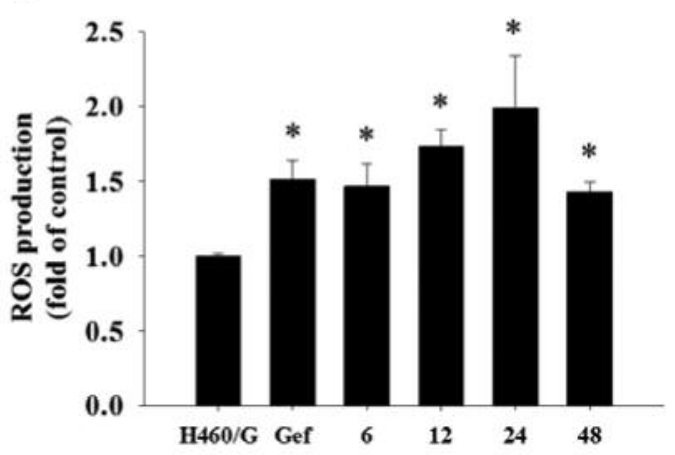

D

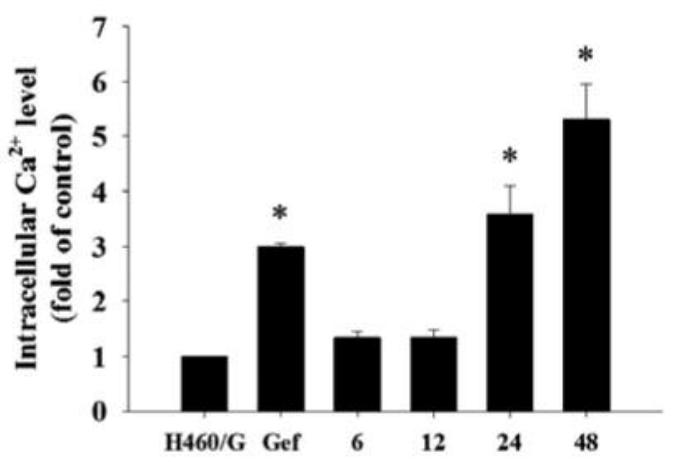

F

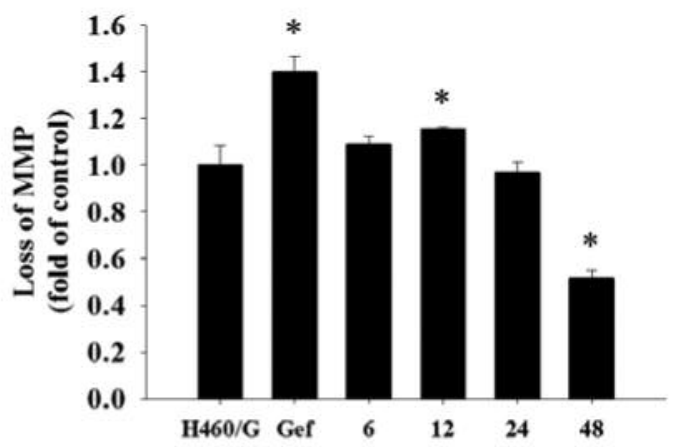

Figure 4. Gefitinib and PEITC affect reactive oxygen species (ROS), intracellular Ca ${ }^{2+}$ and mitochondrial membrane potential $\left(\triangle \Psi_{m}\right)$ in NCI-H460 and NCI-H460/G cells. NCI-H460 and NCI-H460/G cells $\left(1 \times 10^{5}\right.$ cells/well $)$ were incubated with gefitinib $(40 \mu M)$ or PEITC $(25 \mu M$ or $10 \mu M)$ for 6, 12, 24 and $48 \mathrm{~h}$ and were measured for ROS (A: NCI-H460 cells; B: NCI-H460/G cells), Ca ${ }^{2+}(C: N C I-H 460$ cells; D: NCI-H460/G cells) and $\Delta \Psi_{m}\left(E: N C I-H 460\right.$ cells; F: NCI-H460/G cells) as described in Materials and Methods. ${ }^{*} p<0.05$, significant difference between of gefitinib or PEITC-treated group with control group as analyzed by Dunnett test.

Figure 6C and D indicate that PEITC increased Bax, Endo $\mathrm{G}$ and PARP in NCI-H460 and NCI-H460/G cells but decreased Bid expression in NCI-H460 cells (Figure 6C) and increased Bid in NCI-H460/G cells (Figure 6D). Furthermore, PEITC increased GADD153, caspase-7, and calpain 1 in both cells (Figure 6E and F), however, it decreased GRP78 and IRE- $1 \alpha$ in NCI-H460 cells (Figure $6 \mathrm{E})$ but increased GRP78 and decreased IRE-1 $\alpha$ in NCIH460/G cells (Figure 6F). Based on these observations, PEITC-induced apoptotic cell death may proceed via the caspase- and mitochondria-dependent pathways in both cell lines. 
A

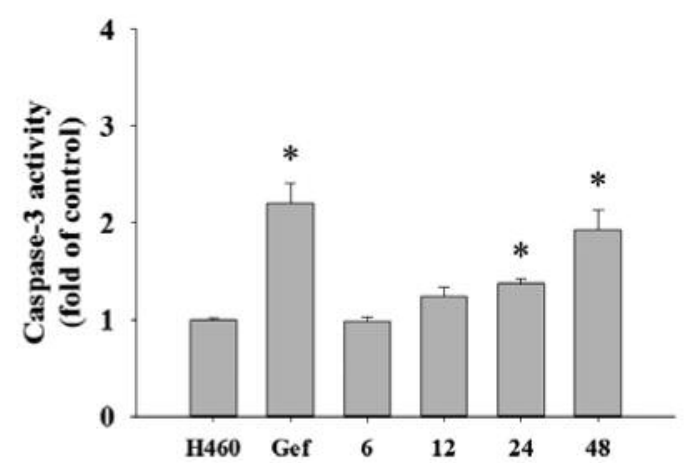

C

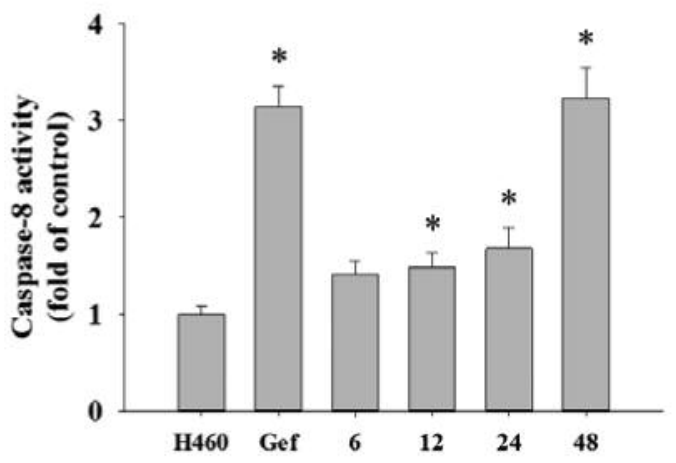

$\mathbf{E}$

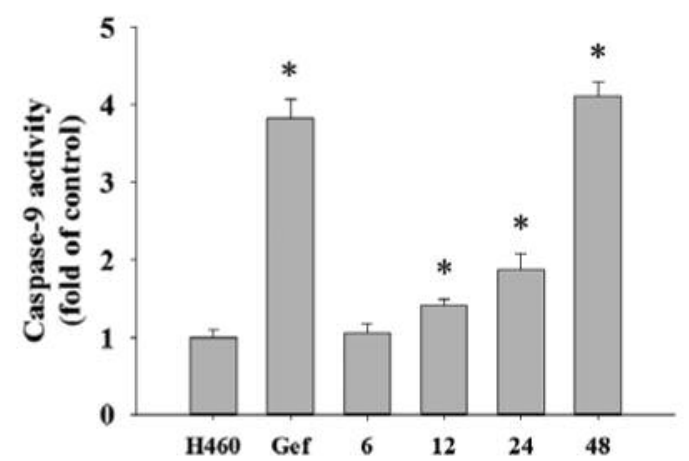

B

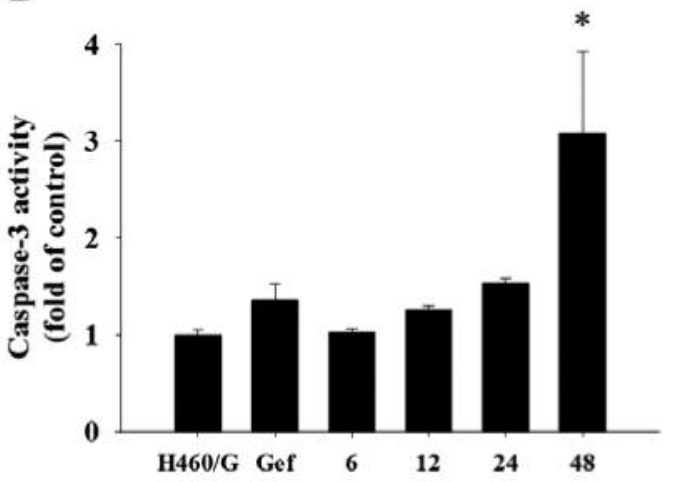

D

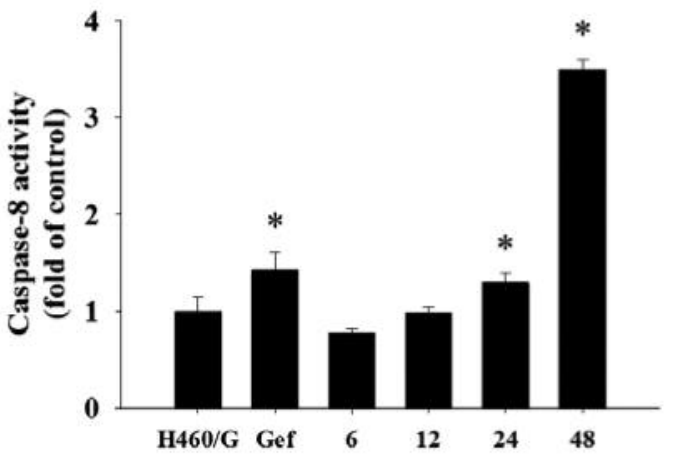

$\mathbf{F}$

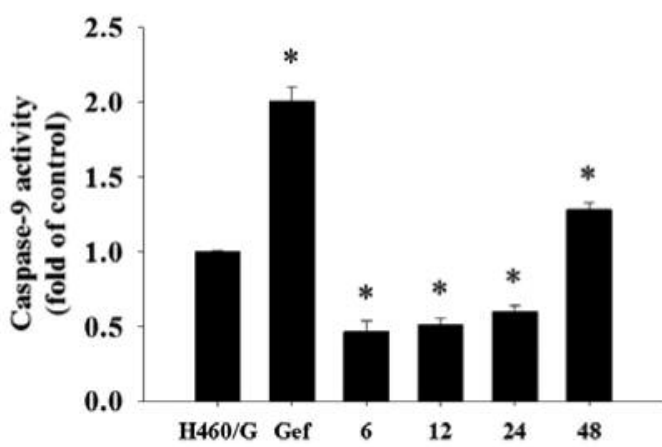

Figure 5. Gefitinib and PEITC induced caspase-3, -8 and -9 activities in NCI-H460 and NCI-H460/G cells. NCI-H460 and NCI-H460/G cells were treated with gefitinib $(40 \mu \mathrm{M})$ or PEITC $(25 \mu \mathrm{M}$ or $10 \mu \mathrm{M}$, respectively) for $6,12,24$ and $48 \mathrm{~h}$ and were measured for activities of caspase-3 (A: NCI-H460 cells; B: NCI-H460/G cells), -8 (C: NCI-H460 cells; D: NCI-H460/G cells) and -9 (E: NCI-H460 cells; F: NCI-H460/G cells) using flow cytometric assay as described in Materials and Methods. Dunnett's test showed a significant difference between gefitinib or PEITC-treated group with the control group. ${ }^{*} p<0.05$.

\section{Discussion}

Gefitinib is clinically used in patients with lung cancer; however, some patients become gefitinib-resistant $(24,25)$, which reduces treatment efficacy. Thus, studies have investigated the use of natural products in order to increase the efficiency of treatment. Numerous studies have shown that PEITC induced apoptotic cell death in human cancer cell lines such as human prostate cancer cells, suppressed the nuclear factor-kB (NF-kB)-regulated gene expression (26) 
A

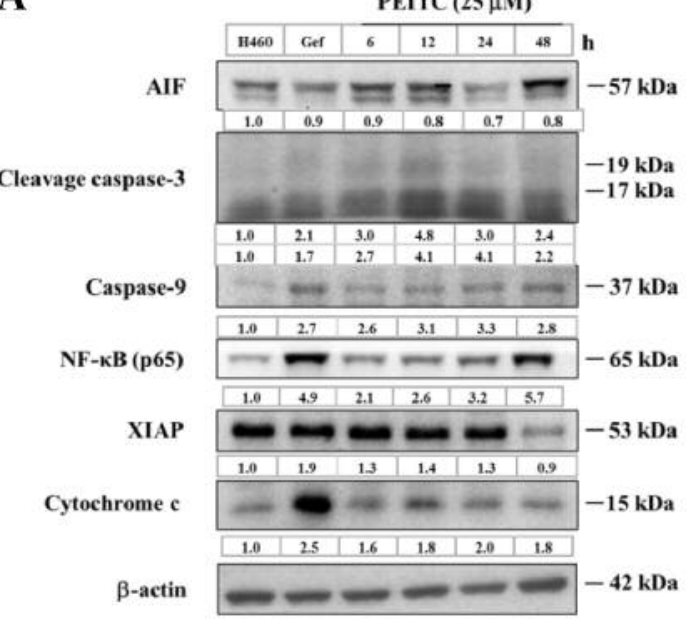

C

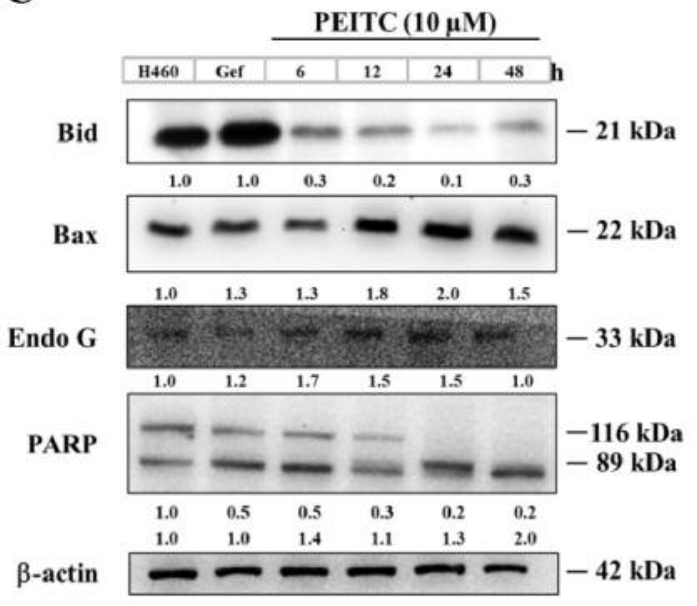

E

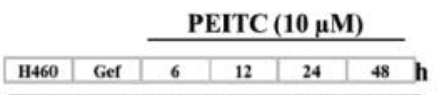

GADD15

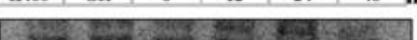

Calpain 1

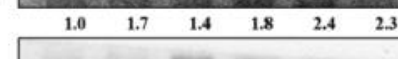

\begin{tabular}{|lllllll}
\hline & & & & & & \\
\hline
\end{tabular}
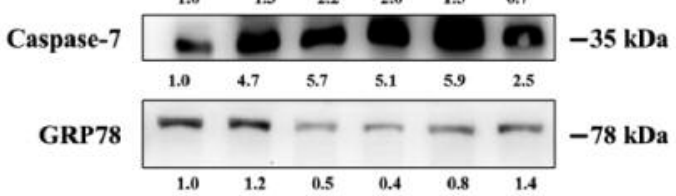

IRE-1a

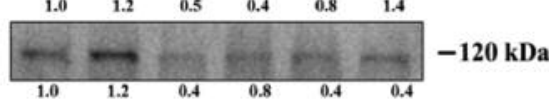

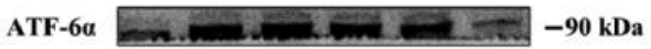

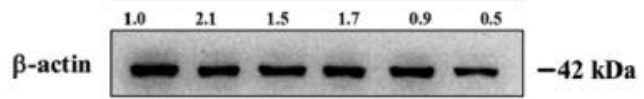

B

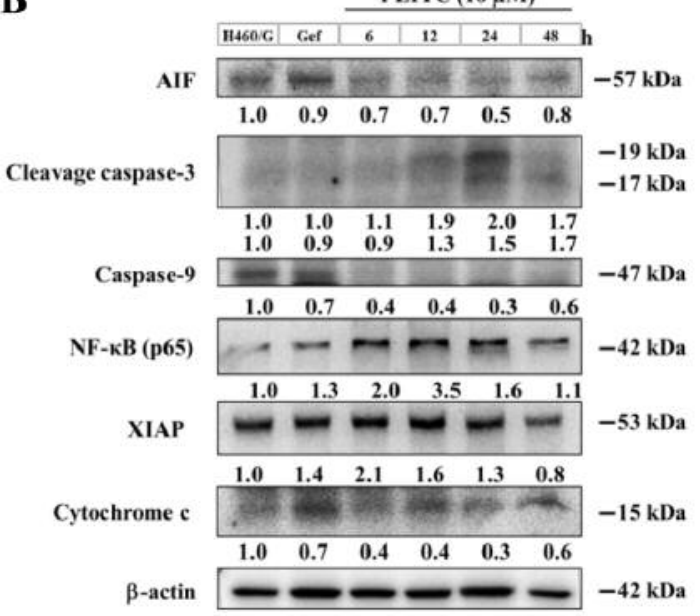

D

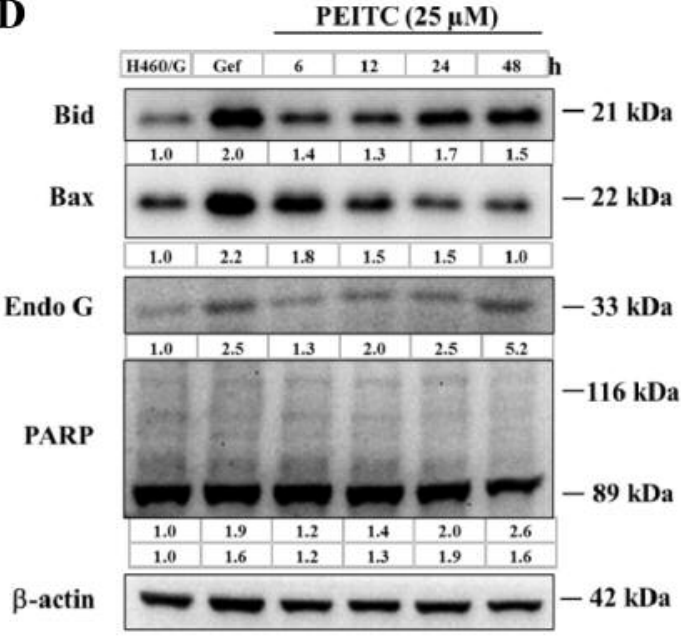

F

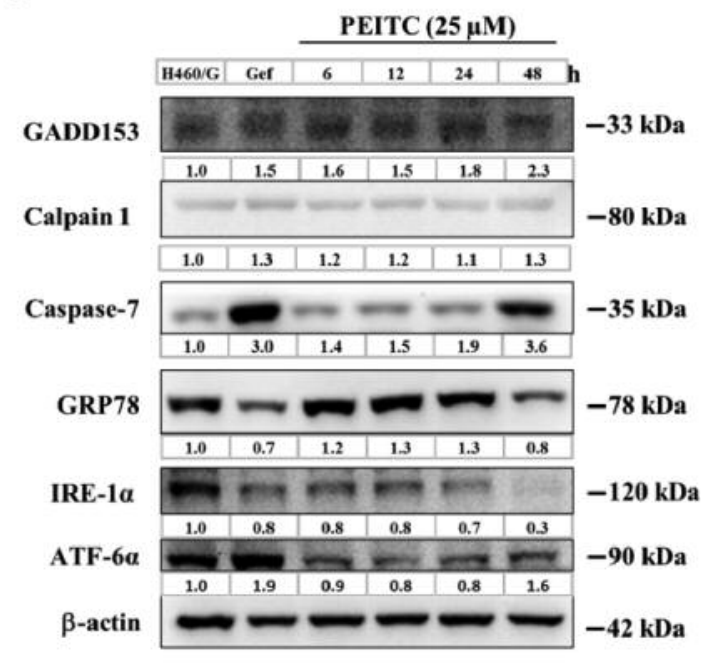

Figure 6. Gefitinib and PEITC altered apoptosis associated protein expression in NCI-H460 and NCI-H460/G cells. Cells were treated with gefitinib $(40 \mu \mathrm{M})$ or PEITC $(25 \mu \mathrm{M}$ or $10 \mu \mathrm{M})$ for $6,12,24$ and $48 \mathrm{~h}$ and proteins were extracted and analyzed by western blotting as described in Materials and Methods. A: NCI-H460 cells; B: NCI-H460/G cells; C: NCI-H460 cells; D: NCI-H460/G cells; E: NCI-H460 cells; F: NCI-H460/G cells. 
and activated the Atg5-mediated autophagy (27). PEITC has also shown antitumor activities in vitro and in vivo $(28,29)$. However, there are no available data showing PEITCinduced apoptotic cell death in gefitinib-resistant NCI-H460 human lung cancer cells (NCI-H460/G cells). Herein, we used flow cytometry to show that PEITC decreased total cell number (Figure 1) via apoptotic cell death which were confirmed using Annexin V/PI staining (Figure 2) and DAPI staining (Figure 3). Furthermore, PEITC increased production of ROS and $\mathrm{Ca}^{2+}$, decreased the levels of $\Delta \Psi_{m}$ (Figure 4B, D and F), and increased caspase- 3 and -8 and 9 activities in NCI-H460/G cells (Figure 5B, D and F). We also used western blotting to show that PEITC increased proapoptotic protein Bax and PARP (Figure 6D) and decreased AIF and cytochrome $c$ expression (Figure 6B) in NCI$\mathrm{H} 460 / \mathrm{G}$ cells.

We used NCI-H460 cells to generate gefitinib-resistant NCI-H460 (NCI-H460/G) cells, as described previously (17). Overall, we found that PEITC decreased the total cell number via the induction of apoptotic cell death in NCI-H460/G cells. The results were confirmed by DAPI staining and Annexin V/PI double staining (30). Evidence has shown that anticancer drugs induce cancer cell apoptosis (31-33). Results indicated that PEITC increased the production of ROS and $\mathrm{Ca}^{2+}$ but decreased the levels of $\Delta \Psi_{m}$ in NCI-H460/G cells (Figure 4B, D and F). ROS are involved in apoptotic cell death (34) and $\mathrm{Ca}^{2+}$ uptake into the mitochondrial matrix plays a role in many cellular functions (35). Endoplasmic reticulum (ER) stress is caused by oxidative stress and can lead to the production of ROS. We suggest that PEITCinduced apoptotic cell death may involve ER stress-related pathways. Thus, we used western blotting assay to show that PEITC increased the expression of hallmarks of ER stress such as GRP78, in NCI-H460/G cells.

Cell cycle arrest and oxidative stress are the main causes of apoptosis $(36,37)$. The intrinsic signaling pathway involves dysfunction of mitochondria and leads to the release of cytochrome $c$ or AIF and Endo G in order to induce apoptosis $(38,39)$. Results indicated that PEITC increased expression of cytochrome $c$ and Endo G in NCI-H460 but only increased Endo G in NCI-H460/G cells (Figure 6C and D). These results also further confirmed that PEITC decreased the levels of $\Delta \Psi_{m}$ in both NCI-H460 and NCIH460/G cells (Figure 4E and F).

Results from flow cytometry assays also showed that PEITC increased caspase- $3,-8$ and -9 activities in both NCIH460 and NCI-H460/G cells (Figure 5). Thus, we suggest that PEITC induced apoptotic cell death via caspase activation. Western blotting also showed that PEITC increased the expression of cleaved caspase-3, caspase-9, NF-kB, XAIP, and cytochrome $c$ in NCI-H460 cells (Figure 6A), but decreased caspase-9 and cytochrome $c$ in NCIH460/G cells (Figure 6B). However, Bax expression was increased in both cell lines after exposure to PEITC (Figure 6C and D). Bax belongs to the BCL family of proteins which are associated with the mitochondria-dependent pathway and death receptor dependent pathway $(40,41)$. These findings indicated that PEITC-induced apoptotic cell death may proceed through the mitochondria-dependent pathway.

Flow cytometric assay showed that PEITC increased ROS production in NCI-H460/G cells (Figure 4B), but decreased ROS in NCI-H460 cells (Figure 4A) after 6-48 h treatment. Western blotting indicated that PEITC increased GADD153 and caspase-7 in both examined cell lines. ATF- $6 \alpha$ was increased after 6-12 h treatment of PEITC in NCI-H460 cells (Figure 6E), but only increased after $48 \mathrm{~h}$ treatment in NCIH460/G cells (Figure 6F). GADD153 and ATF-6 $\alpha$ are hallmarks of ER stress, which is another cause of tumor cell apoptosis $(42,43)$. Thus, as mentioned above, we suggest that PEITC-induced apoptotic cell death may involve ER stress. Based on these observations, the possible molecular mechanism of PEITC-induced apoptotic cell death may involve ROS production accompanied with ER stress in NCIH460 and NCI-H460/G cells. Further studies should be performed in the future to examine these observations in vivo.

\section{Conflicts of Interest}

The Authors do not have any conflicts of interest to disclose.

\section{Acknowledgements}

This work was supported by grant ASIA104-CMUH-05 from Asia University, Taichung, Taiwan. Experiments and data analysis were performed in part through the use of the Medical Research Core Facilities Center, Office of Research \& Development at China Medical University, Taichung, Taiwan.

\section{References}

1 Ferlay J, Steliarova-Foucher E, Lortet-Tieulent J, Rosso S, Coebergh JW, Comber H, Forman D and Bray F: Cancer incidence and mortality patterns in Europe: estimates for 40 countries in 2012. Eur J Cancer 49: 1374-1403, 2013.

2 Devesa SS, Bray F, Vizcaino AP and Parkin DM: International lung cancer trends by histologic type: male:female differences diminishing and adenocarcinoma rates rising. Int J Cancer 117: 294-299, 2005.

3 Bunn PA Jr. and Lilenbaum R: Chemotherapy for elderly patients with advanced non-small-cell lung cancer. J Natl Cancer Inst 95: 341-343, 2003.

4 Torre LA, Bray F, Siegel RL, Ferlay J, Lortet-Tieulent J and Jemal A: Global cancer statistics, 2012. CA Cancer J Clin 65: 87-108, 2015.

5 Siegel R, DeSantis C, Virgo K, Stein K, Mariotto A, Smith T, Cooper D, Gansler T, Lerro C, Fedewa S, Lin C, Leach C, Cannady RS, Cho H, Scoppa S, Hachey M, Kirch R, Jemal A and Ward E: Cancer treatment and survivorship statistics, 2012. CA Cancer J Clin 62: 220-241, 2012. 
6 Perez-Soler R, Chachoua A, Hammond LA, Rowinsky EK, Huberman M, Karp D, Rigas J, Clark GM, Santabarbara P and Bonomi P: Determinants of tumor response and survival with erlotinib in patients with non--small-cell lung cancer. J Clin Oncol 22: 3238-3247, 2004

7 Maemondo M, Inoue A, Kobayashi K, Sugawara S, Oizumi S, Isobe H, Gemma A, Harada M, Yoshizawa H, Kinoshita I, Fujita Y, Okinaga S, Hirano H, Yoshimori K, Harada T, Ogura T, Ando M, Miyazawa H, Tanaka T, Saijo Y, Hagiwara K, Morita S and Nukiwa T: Gefitinib or chemotherapy for non-small-cell lung cancer with mutated EGFR. N Engl J Med 362: 2380-2388, 2010.

8 Jackman D, Pao W, Riely GJ, Engelman JA, Kris MG, Janne PA, Lynch T, Johnson BE and Miller VA: Clinical definition of acquired resistance to epidermal growth factor receptor tyrosine kinase inhibitors in non-small-cell lung cancer. J Clin Oncol 28: 357-360, 2010.

9 Yeomans A, Lemm E, Wilmore S, Cavell BE, Valle-Argos B, Krysov S, Hidalgo MS, Leonard E, Willis AE, Forconi F, Stevenson FK, Steele AJ, Coldwell MJ and Packham G: PEITCmediated inhibition of mRNA translation is associated with both inhibition of mTORC1 and increased eIF2alpha phosphorylation in established cell lines and primary human leukemia cells. Oncotarget 7: 74807-74819, 2016.

10 Yun JH, Kim KA, Yoo G, Kim SY, Shin JM, Kim JH, Jung SH, Kim J and Nho CW: Phenethyl isothiocyanate suppresses cancer stem cell properties in vitro and in a xenograft model. Phytomedicine 30: 42-49, 2017.

11 Yan H, Zhu Y, Liu B, Wu H, Li Y, Wu X, Zhou Q and Xu K: Mitogen-activated protein kinase mediates the apoptosis of highly metastatic human non-small cell lung cancer cells induced by isothiocyanates. Br J Nutr 106: 1779-1791, 2011.

12 Pawlik A, Szczepanski MA, Klimaszewska A, Gackowska L, Zuryn A and Grzanka A: Phenethyl isothiocyanate-induced cytoskeletal changes and cell death in lung cancer cells. Food Chem Toxicol 50: 3577-3594, 2012.

13 Wang D, Upadhyaya B, Liu Y, Knudsen D and Dey M: Phenethyl isothiocyanate upregulates death receptors 4 and 5 and inhibits proliferation in human cancer stem-like cells. BMC Cancer 14: 591, 2014.

$14 \mathrm{Su}$ JC, Lin K, Wang Y, Sui SH, Gao ZY and Wang ZG: In vitro studies of phenethyl isothiocyanate against the growth of LN229 human glioma cells. Int J Clin Exp Pathol 8: 4269-4276, 2015.

15 Boyanapalli SS, Li W, Fuentes F, Guo Y, Ramirez CN, Gonzalez $\mathrm{XP}$, Pung D and Kong AN: Epigenetic reactivation of RASSF1A by phenethyl isothiocyanate (PEITC) and promotion of apoptosis in LNCaP cells. Pharmacol Res 114: 175-184, 2016.

16 Lai KC, Hsiao YT, Yang JL, Ma YS, Huang YP, Chiang TA and Chung JG: Benzyl isothiocyanate and phenethyl isothiocyanate inhibit murine melanoma $\mathrm{B} 16 \mathrm{~F} 10$ cell migration and invasion in vitro. Int J Oncol 51: 832-840, 2017.

17 Huang AC, Yang MD, Hsiao YT, Lin TS, Ma YS, Peng SF, Hsia TC, Cheng YD, Kuo CL and Chung JG: Bufalin inhibits gefitinib resistant NCI-H460 human lung cancer cell migration and invasion in vitro. J Ethnopharmacol 194: 1043-1050, 2016.

18 McDermott M, Eustace AJ, Busschots S, Breen L, Crown J, Clynes M, O'Donovan N and Stordal B: In vitro development of chemotherapy and targeted therapy drug-resistant cancer cell lines: A practical guide with case studies. Front Oncol 4: 40, 2014.
19 Zhang X, Yashiro M, Qiu H, Nishii T, Matsuzaki T and Hirakawa K: Establishment and characterization of multidrugresistant gastric cancer cell lines. Anticancer Res 30: 915-921, 2010.

20 Liu KC, Huang YT, Wu PP, Ji BC, Yang JS, Yang JL, Chiu TH, Chueh FS and Chung JG: The roles of AIF and Endo G in the apoptotic effects of benzyl isothiocyanate on DU 145 human prostate cancer cells via the mitochondrial signaling pathway. Int J Oncol 38: 787-796, 2011.

21 Lee MR, Lin C, Lu CC, Kuo SC, Tsao JW, Juan YN, Chiu HY, Lee FY, Yang JS and Tsai FJ: YC-1 induces $G_{0} / G_{1}$ phase arrest and mitochondria-dependent apoptosis in cisplatin-resistant human oral cancer CAR cells. BioMedicine 7: 12, 2017.

22 Leung YM, Wong KL, Chen SW, Lu DY, Kuo CS, Chen YR, Chen YW and Cheng TH: Down-regulation of voltage-gated $\mathrm{Ca}^{2+}$ channels in $\mathrm{Ca}^{2+}$ store-depleted rat insulinoma RINm5F cells. BioMedicine 3: 130-139, 2013.

23 Liang YC, Hu JC, Li PY, Huang GJ, Kuo YH and Chao CY: Torenia concolor Lindley var. formosana Yamazaki extracts improve inflammatory response and lipid accumulation via PPARs activation. BioMedicine 7: 18, 2017.

24 Tan CS, Gilligan D and Pacey S: Treatment approaches for EGFR-inhibitor-resistant patients with non-small-cell lung cancer. Lancet Oncol 16: e447-e459, 2015.

25 Lin Y, Wang X and Jin H: EGFR-TKI resistance in NSCLC patients: mechanisms and strategies. Am J Cancer Res 4: 411435, 2014.

26 Lee CS, Cho HJ, Jeong YJ, Shin JM, Park KK, Park YY, Bae YS, Chung IK, Kim M, Kim CH, Jin F, Chang HW and Chang $\mathrm{YC}$ : Isothiocyanates inhibit the invasion and migration of $\mathrm{C} 6$ glioma cells by blocking FAK/JNK-mediated MMP-9 expression. Oncol Rep 34: 2901-2908, 2015.

27 Bommareddy A, Hahm ER, Xiao D, Powolny AA, Fisher AL, Jiang Y and Singh SV: Atg5 regulates phenethyl isothiocyanateinduced autophagic and apoptotic cell death in human prostate cancer cells. Cancer Res 69: 3704-3712, 2009.

28 Wang J, Luo B, Li X, Lu W, Yang J, Hu Y, Huang P and Wen S: Inhibition of cancer growth in vitro and in vivo by a novel ROSmodulating agent with ability to eliminate stem-like cancer cells. Cell Death Dis 8: e2887, 2017.

29 Aggarwal M, Saxena R, Sinclair E, Fu Y, Jacobs A, Dyba M, Wang X, Cruz I, Berry D, Kallakury B, Mueller SC, Agostino SD, Blandino G, Avantaggiati ML and Chung FL: Reactivation of mutant p53 by a dietary-related compound phenethyl isothiocyanate inhibits tumor growth. Cell Death Differ 23: 1615-1627, 2016.

30 Liu KC, Shih TY, Kuo CL, Ma YS, Yang JL, Wu PP, Huang YP, Lai KC and Chung JG: Sulforaphane induces cell death through $\mathrm{g} 2 / \mathrm{m}$ phase arrest and triggers apoptosis in HCT 116 human colon cancer cells. Am J Chin Med 44: 1289-1310, 2016.

31 Verheij M, Vens C and van Triest B: Novel therapeutics in combination with radiotherapy to improve cancer treatment: rationale, mechanisms of action and clinical perspective. Drug Resist Updat 13: 29-43, 2010.

32 Sarosiek KA, Ni Chonghaile T and Letai A: Mitochondria: gatekeepers of response to chemotherapy. Trends Cell Biol 23: 612-619, 2013.

33 Yang Y, Zhang Y, Wang L and Lee S: Levistolide a induces apoptosis via ROS-mediated ER stress pathway in colon cancer cells. Cell Physiol Biochem 42: 929-938, 2017. 
34 Koul M, Kumar A, Deshidi R, Sharma V, Singh RD, Singh J, Sharma PR, Shah BA, Jaglan S and Singh S: Cladosporol A triggers apoptosis sensitivity by ROS-mediated autophagic flux in human breast cancer cells. BMC Cell Biol 18: 26, 2017.

35 Chou YC, Chang MY, Wang MJ, Harnod T, Hung CH, Lee HT, Shen CC and Chung JG: PEITC induces apoptosis of Human Brain Glioblastoma GBM8401 Cells through the extrinsic- and intrinsic -signaling pathways. Neurochem Int 81: 32-40, 2015.

36 Siddiqui S, Ahamad MS, Jafri A, Afzal M and Arshad M: Piperine triggers apoptosis of human oral squamous carcinoma through cell cycle arrest and mitochondrial oxidative stress. Nutr Cancer 69: 791-799, 2017

37 Lee $\mathrm{CH}$, Shih YL, Lee MH, Au MK, Chen YL, Lu HF and Chung JG: Bufalin induces apoptosis of human osteosarcoma U2 OS cells through endoplasmic reticulum stress, caspase- and mitochondria-dependent signaling pathways. Molecules 22, 2017. doi: 10.3390/molecules22030437. [Epub ahead of print].

38 Jantas D, Piotrowski M and Lason W: An involvement of PI3K/Akt activation and inhibition of aif translocation in neuroprotective effects of undecylenic acid (UDA) against proapoptotic factors-induced cell death in human neuroblastoma SH-SY5Y cells. J Cell Biochem 116: 2882-2895, 2015.
39 Gupta S, Verma DK, Biswas J, Rama Raju KS, Joshi N, Wahajuddin and Singh S: The metabolic enhancer piracetam attenuates mitochondrion-specific endonuclease $\mathrm{G}$ translocation and oxidative DNA fragmentation. Free Radic Biol Med 73: 278-290, 2014.

40 Zhang H, Holzgreve $\mathrm{W}$ and De Geyter C: Bcl2-L-10, a novel anti-apoptotic member of the Bcl-2 family, blocks apoptosis in the mitochondria death pathway but not in the death receptor pathway. Hum Mol Genet 10: 2329-2339, 2001.

41 Merry DE and Korsmeyer SJ: Bcl-2 gene family in the nervous system. Annu Rev Neurosci 20: 245-267, 1997.

42 Sano R and Reed JC: ER stress-induced cell death mechanisms. Biochim Biophys Acta 1833: 3460-3470, 2013.

43 Verfaillie T, Garg AD and Agostinis P: Targeting ER stress induced apoptosis and inflammation in cancer. Cancer Lett 332: 249-264, 2013
Received February 13, 2018

Revised March 6, 2018

Accepted March 12, 2018 